\title{
Long-lasting enhancement of synaptic excitability of.CA1/subiculum neurons of the rat ventral hippocampus by vasopressin and vasopressin( 4-8)
}

\author{
A.N. Chepkova ", P. French a, D. De Wied ", A.H. Ontskul ', G.M.J. Ramakers ", V.G. Skrebitski ", \\ W.H. Gispen ${ }^{\text {a }}$, I.J.A. Urban ${ }^{\text {a. * }}$ \\ 'Rudolf Magnus Institute for Neurosciences, University of Utrecht, PO Box 80040, 3508 TA Utrecht, The Netherlands \\ ${ }^{b}$ Institute for Brain Research, Per. Obukha 5, Moscow, Russian Federation
}

Accepted 25 July 1995

\begin{abstract}
Vasopressin (VP) is axonally distributed in many brain structures, including the ventral hippocampus. Picogram quantities of VP injected into the hippocampus improve the passive avoidance response of rats, presumably by enhancing memory processes. Vasopressin is metabolized by the brain tissue into shorter peptides, such as $\left[\mathrm{pGlu}{ }^{4}, \mathrm{Cyt}^{6}\right] \mathrm{VP}(4-9)$ and $\left[\mathrm{pGlu}^{4}, \mathrm{Cyt}^{\prime}\right] \mathrm{VP}(4-8)$. which preserve the behavioral activity but lose the peripheral activities of the parent hormone. Using brain slices, we investigated whether VP or VP(4-8) affects excitatory postsynaptic potentials (EPSPs) and/or membrane responses to depolarization in neurons of the CA1/subiculum of the ventral hippocampus. The EPSPs were evoked by stimulating the stratum radiatum of the CAl field; the membrane responses were elicited by current injections. Exposure of slices for $15 \mathrm{~min}$ to $0.1 \mathrm{nM}$ solution of these peptides resulted in an increase in the amplitude and slope of the EPSPs in 21 neurons $(67 \%)$ tested. No consistent change in either the resting membrane potential or the input resistance of the neurons was observed. The peptide-induced increase in EPSPs reached a maximum $30-45$ min after peptide application. In 14 of these neurons $(66 \%)$, the peptide-induced increase in EPSPs remained throughout the entire $60-120$ min washout period. In the remaining 7 neurons $(33 \%)$, the initial increase in EPSPs amplitude was followed by a gradual decline to the pre-administration level. The increase in EPSP amplitude was often. but not always, associated with a decrease in the threshold and increase in the number of action potentials in response to depolarizing current injection. Suppression of $\mathrm{GABA}_{\mathrm{A}}$ receptor-mediated inhibition and $N$-methyl-D-aspartate (NMDA) receptor-mediated excitation did not prevent the effects of VP and VP(4-8) on the EPSP amplitude or the threshold for action potentials. The results demonstrate that $0.1 \mathrm{nM}$ concentrations of these neuropeptides can elicit a long-lasting enhancement of the excitability of $\mathrm{CAl}$ /subiculum neurons of the ventral hippocampus to excitatory, glutamatergic synaptic input. This novel action of VP and its metabolite in the ventral hippocampus may be the physiological action, mediating the memory-enhancing effect of these peptides.
\end{abstract}

Keywords: Vasopressin: Vasopressin(4-8); Hippocampus; Transmission; Potentiation; Excitability

\section{Introduction}

The CAl/subiculum of the ventral hippocampus is one of the brain structures in which vasopressin (VP)- and oxytocin (OT)-containing fibers $[8,16]$ and specific binding sites for these hormones have been found [23,24,34,63]. Centrally administered VP improves avoidance behavior, stimulates the maintenance of tolerance to alcohol, and affects the regulation of the body temperature and many other physiological parameters (for review see [20]).

\footnotetext{
* Corresponding author. Rudolf Magnus Institute for Neurosciences, PO Box 80041). 3508 TA Utrecht, The Netherlands. Fax: (31) (30) 539032 .
}

Learning of a passive avoidance response and retrieval or relearning of an Go-No Go discrimination task is markedly improved by picogram quantities of $V P$ or $V P(4-9)$ injected into the ventral hippocampus of rat or mice $[32,42]$. indicating that the peptides have a strong influence on the functioning of this structure. The brain metabolizes VP into shorter peptides, such as $\left[\mathrm{pGlu}{ }^{4}, \mathrm{Cyt}^{6}\right] \mathrm{VP}(4-9)$ or $\left[\mathrm{pGlu}^{4}, \mathrm{Cyt}^{6}\right] \mathrm{VP}(4-8)$, that are even more potent than VP in improving the learning of a passive avoidance response $[9,19]$ but which lack the pressor and/or antidiuretic activity of the parent hormone [14]. On the basis of these and other experiments (for review see [20]), it has been suggested that brain VP and VP metabolites may function as memory-facilitating principles [18]. The beneficial effect of centrally administered VP or VP(4-8) on the learning 
of a passive avoidance response was demonstrated when the peptide was administered $60 \mathrm{~min}$ prior to learning [17] and immediately thereafter [33], but also when the learning trial was given $3 \mathrm{~h}$ after VP administration [25]. Thus, the memory-enhancing effect of VP and VP(4-8) is presumably the result of a long-lasting modulatory action on the neurotransmission and/or membrane excitability of neurons in the hippocampus and presumably in other brain structures.

The action of microiontophoretically or bath-applied micromolar concentrations of VP on hippocampal and other brain neurons is predominantly an excitatory one, characterized by a reversible increase in the firing rate that vanishes immediately or within several minutes after the termination of peptide administration $[28,38,43,45,62,67]$. In vitro, micromolar concentrations of VP are usually needed to demonstrate this excitatory action of VP in a significant population of neurons, suggesting that these short-lasting excitations are presumably not the action by which the picogram quantities of VP or its active metabolites facilitate memory. Most of the lateral septum and ventral hippocampal neurons that were not excited by iontophoretically applied VP exhibited a marked increase in their responses to iontophoretically released glutamate, an effect which lasted for tens of minutes after the termination of peptide application [29,67]. Also, the synaptic responses of lateral septum neurons to stimulation of the fimbria fibers, that are presumably mediated by glutamate $[30,73]$, were markedly potentiated by iontophoretically applied VP [29]. These findings suggested that the brain $\mathrm{VP}$ and/or its metabolites may function as a long-acting principle, facilitating the neuronal responses to an excitatory, glutamatergic input [64]. The long-lasting facilitation by $0.1 \mathrm{nM}$ vasopressin of the excitatory postsynaptic potentials (EPSPs) in lateral septum neurons, evoked by stimulating the fimbria fibers [69], supports this notion. However, the action of picomolar concentrations of VP and VP(4-8) on the excitability and glutamatergic transmission of neurons in the ventral hippocampus has not yet been investigated, although some data for the dorsal hippocampus have been recently published $[12,52]$. The aim of the study is to examine, by using intracellular electrodes in brain slices, whether $0.1 \mathrm{nM}$ VP and VP(4-8) affect the excitability and/or the amplitude of the glutamatergic EPSPs evoked in the CA1/subiculum neurons of the ventral hippocampus by stimulation of the radiate layer. [68].

\section{Materials and methods}

Male Wistar rats $(80-120 \mathrm{~g})$ were decapitated and the right hippocampus was dissected from the brain by a cortical approach. Transverse, $450 \mu \mathrm{m}$ thick slices of the ventral hippocampus were prepared, using a McIlwain tissue chopper, and placed into oxygenated medium at room temperature. The connection between the CA1 and CA 3 fields was interrupted by a transverse cut through all the layers in order to eliminate the spread of activity from the CA3 field of the hippocampus [11]. After approximately $1 \mathrm{~h}$, the slices were transferred to recording chambers [65], fixed between two nylon nets, and superfused at a rate of $1.5 \mathrm{ml} / \mathrm{min}$ with warm $\left(32^{\circ} \mathrm{C}\right)$, carbogenated $\left(95 \% \mathrm{O}_{2} ; 5 \% \mathrm{CO}_{2}\right)$ medium of the following composition (in $\mathrm{mM}$ ): $\mathrm{NaCl}$ (124), $\mathrm{KCl}$ (3.5), $\mathrm{CaCl}_{2}$ (2.5), $\mathrm{MgSO}_{4}$ (1.4), $\mathrm{NaH}_{2} \mathrm{PO}_{4}$ (1.25), $\mathrm{NaHCO}_{3}$ (26) and D-glucose (10). A bipolar stimulating electrode, made of stainless steel wire of $50 \mu \mathrm{m}$ diameter, insulated except at the tip and positioned in the stratum radiatum, was used to evoke the synaptic responses in neurons of the CA1/subiculum fields. The neurons were impaled with glass microelectrodes filled with either $4 \mathrm{M}$ potassium acetate (KAc; resistance $60-120 \mathrm{M} \Omega$ ) or $3 \mathrm{M} \mathrm{KCl}$ (resistance $40-90$ $\mathrm{M} \Omega$ ). The KAc-filled electrodes were used in slices with intact inhibitory pathways and superfused with the normal medium. $\mathrm{KCl}$-filled microelectrodes were used in slices in which the $\mathrm{GABA}_{\mathrm{A}}$ receptor-mediated synaptic inhibition was suppressed by picrotoxin. Membrane potentials were recorded with a Dagan 8100 amplifier and monitored on an oscilloscope. The resting membrane potential (RMP) was monitored on a chart recorder. The actual value of RMP was determined from the voltage step produced by withdrawal of the microelectrode from the cell. Computer-generated stimuli were used to evoke synaptic or membrane responses. These stimuli, which were fed either into a stimulus-isolating constant current circuit or into the current-injection circuit of the amplifier, were reproducible at all times and allowed comparison of the stimulus-response relationship of the EPSPs and membrane responses to depolarizing current injection (threshold for action potential) in neurons before, during, and after treatment with the peptides. A hyperpolarizing current of $100-300 \mathrm{pA}$ intensity and $30-60 \mathrm{~ms}$ duration was applied before the stimulus in each of the EPSP sweeps in order to monitor the resting input resistance $\left(R_{(I N)}\right)$ of the cell throughout the experiment. Whenever a disbalance of the bridge circuit was noticed, a $1 \mathrm{~ms}$ buzzer pulse was applied to clean the tip and/or the bridge was re-adjusted.

\subsection{Experimental protocol}

The neurons that exhibited a stable resting membrane potential (RMP) of at least $-60 \mathrm{mV}$, an action potential $>70 \mathrm{mV}$, an $\mathrm{R}_{(\mathrm{IN})}>35 \mathrm{M} \Omega$ which responded to stimulation (monophasic constant current pulse of $0.1 \mathrm{~ms}$ duration) of the stratum radiatum with EPSPs of at least $4 \mathrm{mV}$ were included in the study. In the first $20-30 \mathrm{~min}$ of the experiment, the stimulus intensity required to evoked EPSPs of half the maximum amplitude that evoked an action potential was determined and baseline EPSPs elicited by at least 3 series of 10 stimuli $(0.1 \mathrm{~Hz})$ at 5 -min intervals were 
obtained. In addition, 3-5 membrane potential responses to a depolarizing current of $100-400 \mathrm{pA}$ and $300-400 \mathrm{~ms}$ were recorded. In some neurons, EPSPs evoked by a series of 10 stimuli of increasing intensity were recorded in order to determine the stimulus-response relationship in the EPSPs prior to peptide treatment. The superfusion medium was switched for 15 min to a medium containing $0.1 \mathrm{nM}$ arginine ${ }^{\mathrm{y}}-\mathrm{VP}$ (Organon) or $\left[\mathrm{pGlu}^{4}, \mathrm{Cyt}^{6}\right]$-arginine ${ }^{\mathrm{x}}-\mathrm{VP}(4-$ 8) (VP4-8; Organon). EPSPs elicited by a series of 10 stimuli applied at 5-min intervals were recorded during this period. The superfusion was then switched back to the control medium for the rest of the recording session. In many neurons, the stability of the responses allowed us to record EPSPs and membrane responses to depolarization for at least $60 \mathrm{~min}$ after peptide administration. In some experiments, the effect of peptides was studied during superfusion of the slices with a medium containing 10-50 $\mu \mathrm{M}$ picrotoxin (Sigma) or picrotoxin and $10-50 \mu \mathrm{M}$ D-2-amino-5-phosphonovaleric acid (D-APV; $\alpha$ CRB).

\subsection{Data analysis}

The synaptically and current-induced membrane potentials were digitized $(20 \mathrm{kHz})$ and stored in a personal computer, using p-Clamp software (Axon Instruments Inc.) which computes, stores and prints the average EPSPs, peak amplitude (in $\mathrm{mV}$ ), latency (in $\mathrm{ms}$ ) and slope (in $\mu \mathrm{V} / \mathrm{ms}$ ) of the EPSPs. The slope was computed from the voltage at two fixed time intervals in the rising phase of the EPSPs. In addition, $\mathrm{R}_{(\mathrm{IN})}$ was computed from the voltage response to hyperpolarizing current injections, and the voltage and the time to the onset of the action potential elicited by depolarizing current injection (threshold for action potential) were determined. The average EPSPs amplitude, slope. and $R_{(I N)}$ during and after peptide treatment are expressed
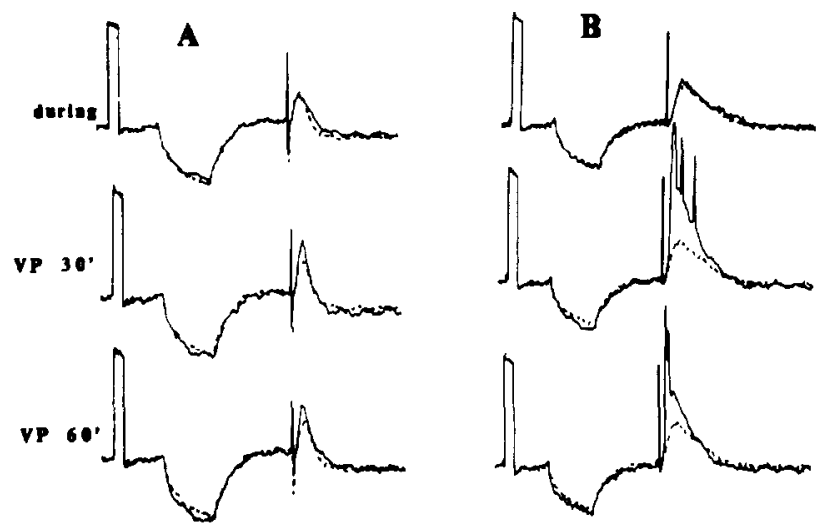

Fig. 1. Example of average $\operatorname{EPSPS}_{(n=10)}$ in two CA1/subiculum neurons ( $\mathrm{A}$ and $\mathrm{B}$ ), recorded with KAc-filled electrode (see Methods), before (dotted line), 30 and 60 min after treatment with $0.1 \mathrm{nM} \mathrm{VP}$ in control medium. The action potentials superimposed on EPSPs in neuron $B$ were truncated by averaging. The resting membrane potential of neurons $A$ and $B$ was -68 and $-63 \mathrm{mV}$, respectively. The hyperpolarizing current in $A$ and $B$ was 0.2 and $0.1 \mathrm{nA}$, respectively. Calibration: 10 $\mathrm{mV}$ and $5 \mathrm{~ms}$.
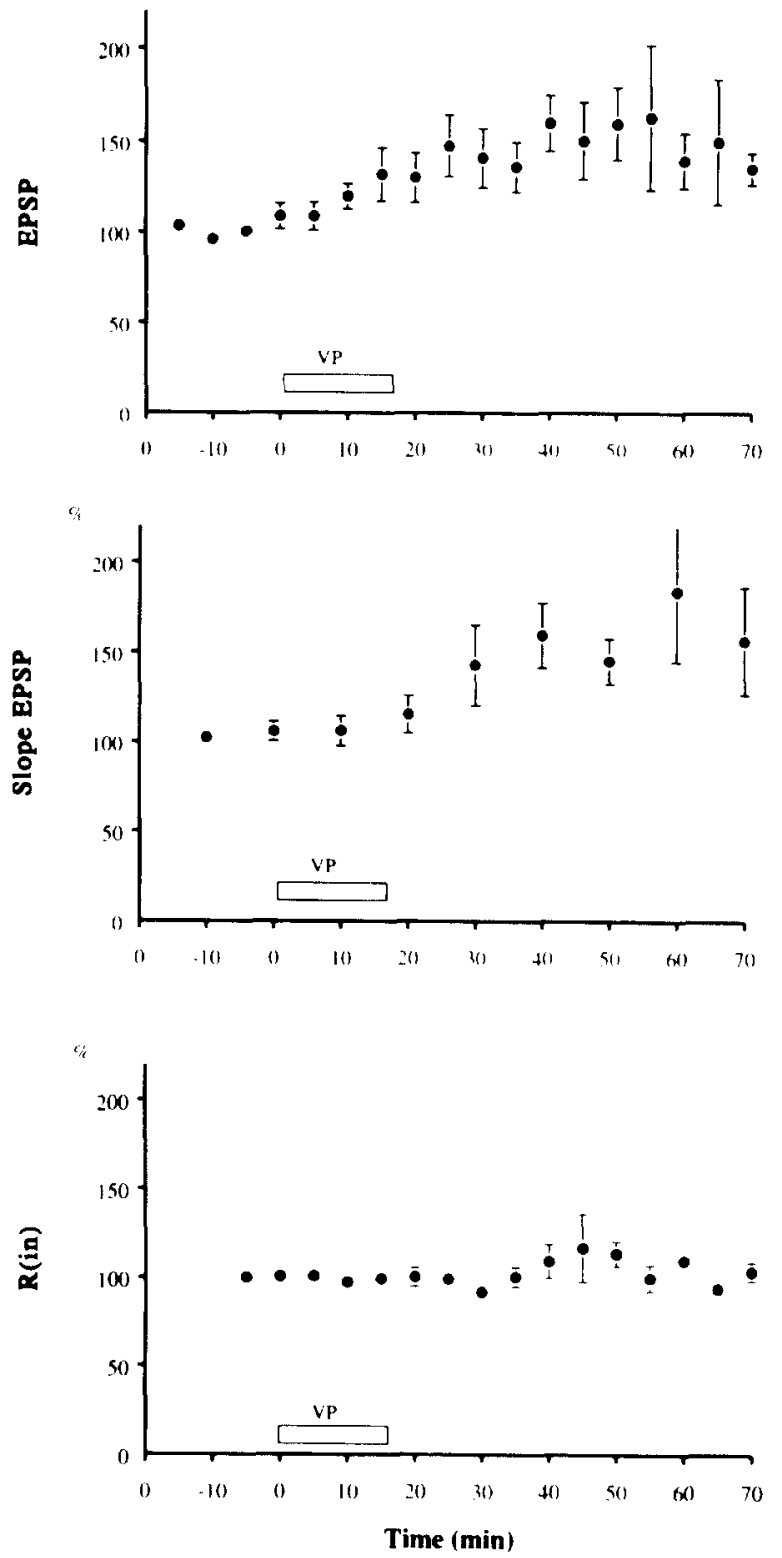

Fig. 2. Effect of $0.1 \mathrm{nM}$ VP on the amplitude and slope of the EPSPs and on the input resistance $\left(R_{1 \mathrm{~N}}\right)$ in $21 \mathrm{CAl} /$ subiculum neurons of the ventral hippocampus. Mean values of the mean $( \pm$ SEM $)$ are expressed as percentages of the baseline values. Open bar indicates the time of the 15-min administration of peptide. The mean EPSPs at 60$) \min (n=1 \%$. see Results) was significantly different $(t=5.874 . P<0.00) 1$ in two-tailed $t$-test for related measurements) from the control EPSPs.

as percentages of the average baseline of these parameters before peptide treatment. The significance of the peptide treatment was assessed by comparing the mean baseline values with the mean values obtained $60 \mathrm{~min}$ after peptide administration in a two-tailed paired $t$-test for related measurements.

\section{Results}

The neurons included in the study $(n=72)$ had an RMP of $-63.6 \pm 4.6$ (mean \pm SEM) $\mathrm{mV}$, an $\mathrm{R}_{(\mathrm{IN})}$ of 


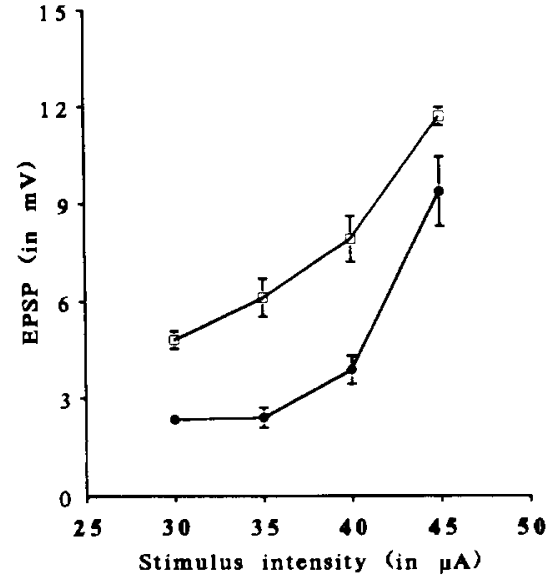

Fig. 3. The stimulus-response relationship of the average EPSPs in one of the CAl/subiculum neurons before (filled symbols) and $60 \mathrm{~min}$ after (open symbols) treatment with $0.1 \mathrm{nM}$ VP.

$46.8 \pm 6.5 \mathrm{M} \Omega$, and an action potential amplitude of $86.7 \pm 3.9 \mathrm{mV}$. The average stimulus intensity used to evoked EPSPs was $59.9 \pm 39.8 \mu \mathrm{A}$. The average amplitude of the EPSPs was $4.9 \pm 0.4 \mathrm{mV}$.

\subsection{Effect of $V P$}

The effect of $0.1 \mathrm{nM}$ VP on EPSPs in slices superfused with control medium was studied in 27 neurons. Data from 6 of these neurons were excluded from the final analysis because the amplitude of the EPSPs decreased irreversibly during the experiment $(n=4)$, or because the membrane potential became instable during the first $10-15 \mathrm{~min}$ of the washout period $(n=2)$. The data from the remaining 21 neurons were analyzed. In 14 of these neurons $(67 \%)$, the

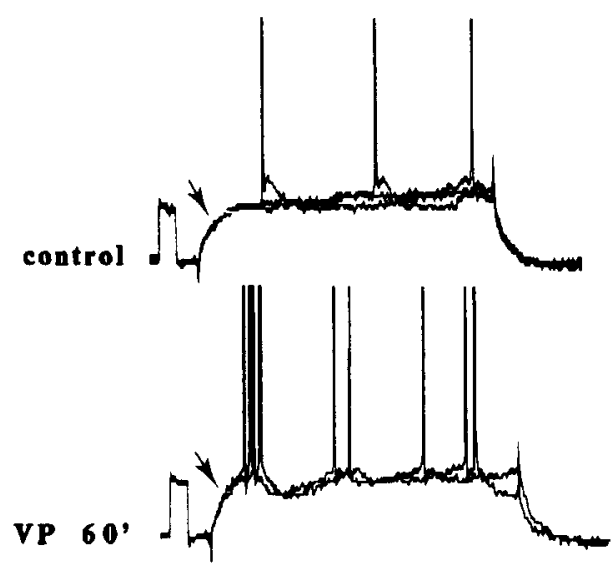

Fig. 4. Typical example of the effect of $0.1 \mathrm{nM} \mathrm{VP}$ on the response of the postsynaptic membrane of $\mathrm{CA} 1$ /subiculum neurons to depolarizing current injection of $250 \mathrm{pA}$. Upper panel: three superimposed sweeps of the responses before treatment with VP; lower panel: three superimposed sweeps of the membrane responses $60 \mathrm{~min}$ after VP treatment. The resting membrane potential of the neuron was $-65 \mathrm{mV}$. Note the steeper rising phase (arrow) and increased number of action potentials (partially truncated) after VP treatment (lower panel). Calibration: $10 \mathrm{mV}$ and 10 ms.

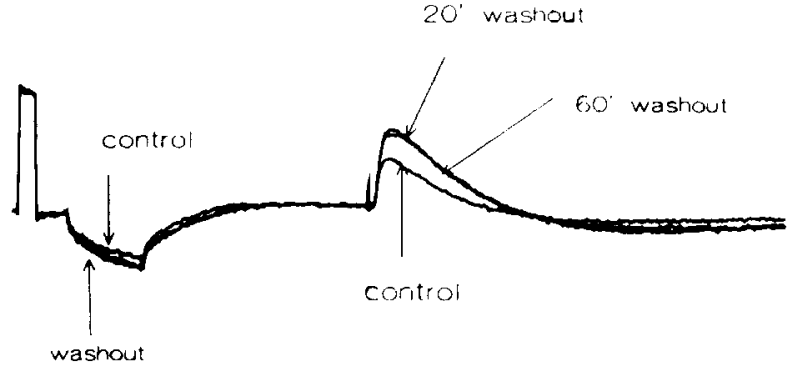

Fig. 5. Typical example of the effect of $0.1 \mathrm{nM}$ VP on EPSPs in a neuron pretreated for $30 \mathrm{~min}$ with $50 \mu \mathrm{M}$ picrotoxin before VP application. Superimposed are the sweeps of average $(n=10)$ EPSPs before (control), $20\left(20^{\prime}\right)$ and $60\left(60^{\prime}\right)$ min after treatment with VP. Note that picrotoxin was present in the medium for the entire recording period. Also note a small increase in the response to hyperpolarizing current injection of 125 $\mathrm{pA}$ in this neuron after peptide treatment. Calibration: $10 \mathrm{mV}$ and $10 \mathrm{~ms}$.

amplitude of average EPSPs 60 min after VP administration was markedly increased compared to the baseline amplitude, while the $R_{\text {(IN) }}$ of the neurons changed little (see example in Fig. 1A). In 5 of these neurons (see example in Fig. 1B), an EPSP spike complex appeared after VP treatment. In the remaining 7 neurons, the initial increase in EPSPs diminished during the washout period $(n=4)$, or the EPSPs were not changed by VP $(n=4)$. Fig. 2 summarizes the effect of VP treatment on the EPSPs, on the slope of the EPSPs, and on the $R_{(I N)}$ in these 21 neurons. Typically, the EPSP amplitude started to rise at the end of the VP application or during the first minutes of the washout period. The amplitude reached a plateau within 30-45 min. Thereafter, it either stayed at the same level for the rest of the recording, lasting 60-120 min, or it gradually declined. However, the mean amplitude of EPSPs at $60 \mathrm{~min}$ was significantly $(t=5.874$; $P<0.001$ in two-tailed paired $t$-test) higher than the baseline amplitude. Also, the slope of EPSPs of these neurons often increased after VP application although the variability of the slope increase was considerably greater than that of the amplitude increase. Although the mean $R_{(I N)}$ was little affected by VP (see Fig. 2), a temporary change of $5-30 \%$ during and/or after the application of VP was observed in approximately $35 \%$ of the neurons. Membrane leakage and/or adherence of membranes to the electrode tip might have contributed to these apparently treatmentunrelated fluctuations in $R_{(I N)}$. Three out of four neurons, tested before and $60 \mathrm{~min}$ after VP treatment, exhibited an increase in the stimulus-response relationship of the EPSPs (see example in Fig. 3). Five other neurons were studied with $0.001 \mathrm{nM}$ of VP in the medium. The average EPSPs in these neurons changed little after the peptide administration, being at $60 \mathrm{~min}$ of the washout period 92.4-112.8\% of the control level prior to VP administration (not shown). Higher VP concentrations did not seem to markedly augment the effect. In 3 out of 4 neurons studied with $1 \mathrm{nM}$ VP, the average amplitude of EPSPs at $60 \mathrm{~min}$ after the VP administration was 149.6-192.6\% of the baseline, 
while EPSP in the one neuron was decreased by $14.7 \%$ after VP administration. In 4 out of 6 other neurons exposed to $10 \mathrm{nM} \mathrm{VP,} \mathrm{the} \mathrm{EPSP} \mathrm{amplitude} \mathrm{at} 60 \mathrm{~min}$ after VP administration was $126.8-174.9 \%$ of the control EPSPs before the peptide administration (not shown), the 2 remaining neurons showed no treatment-related change in the EPSP amplitude. However, whenever the amplitude of EPSPs was increased by 1.0 or $10 \mathrm{nM} \mathrm{VP,} \mathrm{the} \mathrm{increase}$ remained present for the entire recording period (60-150 $\mathrm{min})$. In that the effect differed from that induced by 0.1 nM VP which in some cells disappeared within the $60 \mathrm{~min}$ washout period. A repeated administration of $0.1 \mathrm{nM} \mathrm{VP}$, performed in two neurons in which EPSPs increased after the first administration of VP, failed to produce an additional increase in the EPSP amplitude (not shown).

We compared the voltage and latency of the first action potential fired in response to depolarizing current injections administered before and after VP treatment in 10 neurons in which EPSPs were potentiated by $V P$ and in
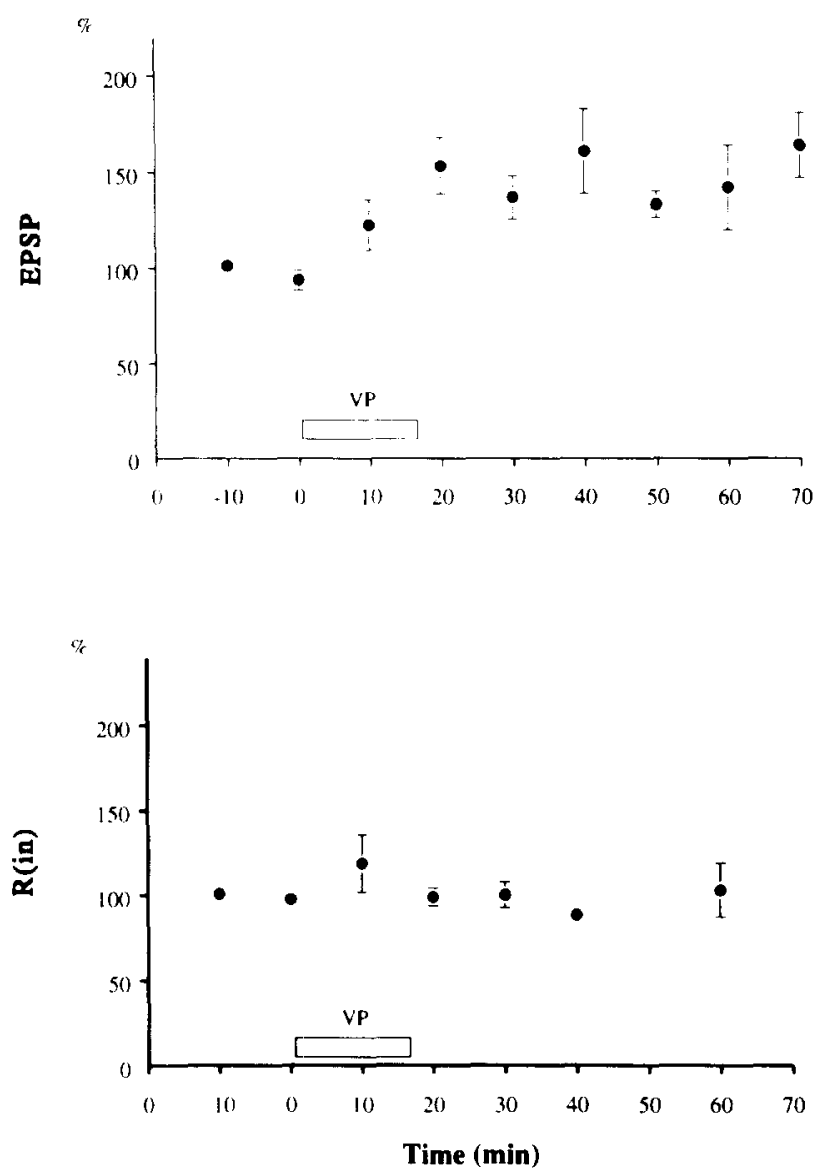

Fig. 6. Effect of $0.1 \mathrm{nM}$ VP on EPSPs and input resistance $\left(R_{(\mathrm{IN})}\right)$ in eight $\mathrm{CA} 1$ /subiculum neurons of the ventral hippocampus in the presence of picrotoxin and D-APV in the medium. Plotted are the means $( \pm$ SEM) of the measurements obtained at 10 -min intervals. A temporary increase in variability of $R_{(I N}$, during administration of the peptide was seen in five of the neurons. The mean EPSP at $60 \mathrm{~min}$ was significantly different from that at baseline $(t=2.486 ; P<0.05$ in two-tailed $t$-test for repeated measurements). The mean $R_{(I N)}$ at $50 \mathrm{~min}$ is missing because data were accidentally lost
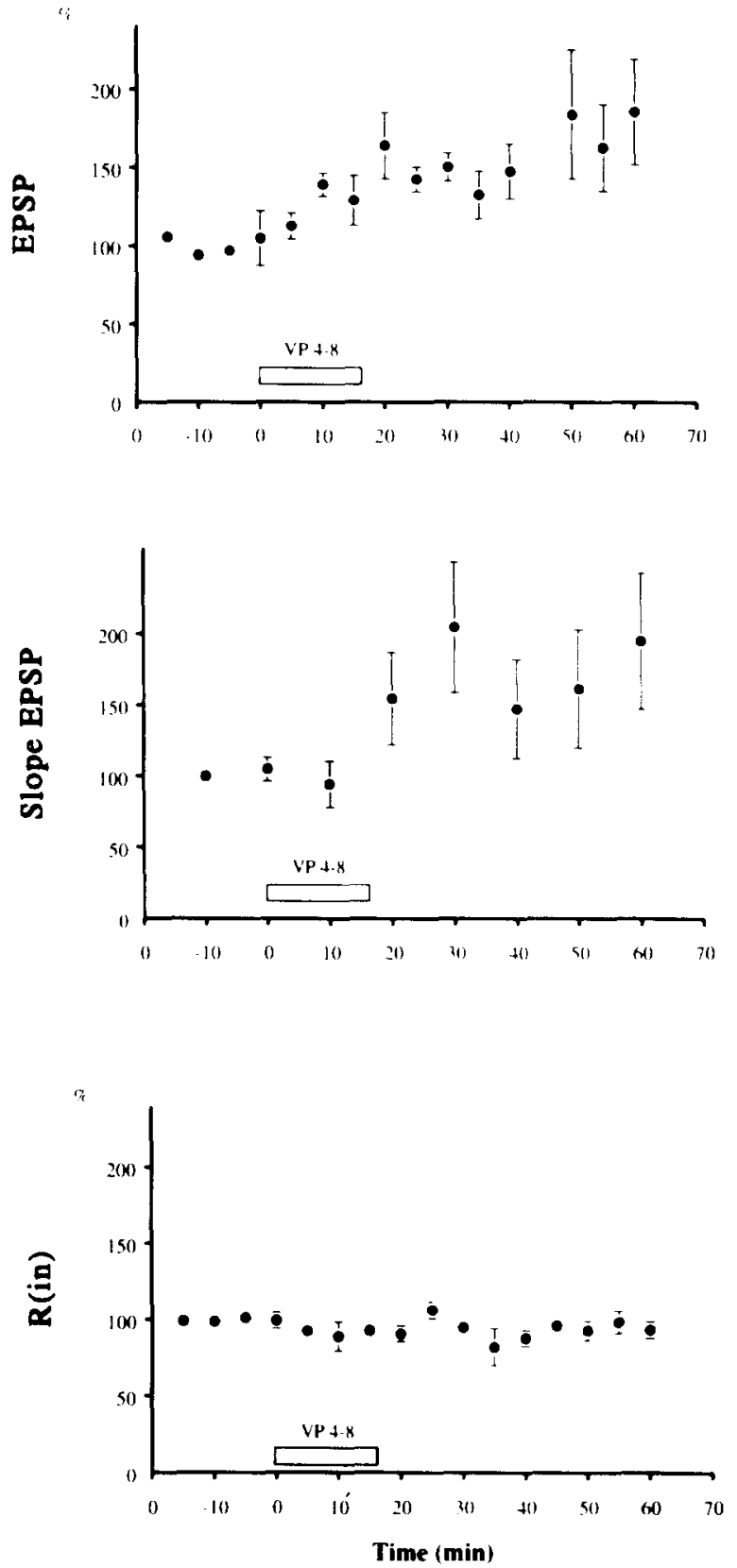

Fig. 7. Effect of $0.1 \mathrm{nM} \mathrm{VP(4-8)}$ on the amplitude and slope of EPSPs and the input resistance $\left(\mathrm{R}_{\mathrm{fIN}}\right)$ in $10 \mathrm{CAl} /$ subiculum neurons of the ventrat hippocampus, expressed as percentages of baseline values. Open bar indicates the time of the 15 -min administration of peptide. The mean $( \pm$ SEM) amplitude and slope of EPSPs at 60 min were significantly different from those of the controls (amplitude: $t=2.282, P<0.05$ : slope: $t=2.269$ in two-tailed $t$-test for related measurements). The value of the mean of EPSPs at 50 min is missing

which the RMP remained stable $( \pm 1 \mathrm{mV})$ during washout. No significant difference was found in means $(n=10)$ of either parameter: the mean threshold for action potential was $11.22 \pm 1.9 \mathrm{mV}$ before $\mathrm{VP}$ and $9.76 \pm 1.7 \mathrm{mV} 60 \mathrm{~min}$ after VP $(t=1.76 ; P=0.112)$; the action potential occurred at $128.07 \pm 26.8 \mathrm{~ms}$ in controls versus $91.85 \pm 29.0$ $\mathrm{ms}$ after VP treatment $(t=1.30 ; P=0.226)$. However, in 8 of these neurons, the rising phase of the membrane 
response became steeper, the neurons started to fire earlier, and the number of action potentials during depolarization increased after VP treatment (see example in Fig. 4). Two other cells showed an increase in the latency and threshold of the action potential after the treatment with $0.1 \mathrm{nM}$ VP (not shown). Higher concentrations (1 and $10 \mathrm{nM}$ ) of VP were also associated with a similar, long-lasting increase in the rising phase of the membrane response and in the number of action potentials fired in response to depolarizing current injection (not shown).

Seven neurons were studied with $\mathrm{KCl}$-filled electrodes in slices in which $\mathrm{GABA}_{\mathrm{A}}$ receptor-mediated inhibition was suppressed by superfusing the slice for $30 \mathrm{~min}$ before VP administration with a medium containing $10-50 \mu \mathrm{M}$ picrotoxin. Four of these neurons exhibited a $20-100 \%$ $(150.1 \pm 15.2 \%$ of the baseline level) increase in the amplitude of EPSPs $60 \mathrm{~min}$ after VP administration (see example in Fig. 5). The EPSP increase in the remaining cells either diminished during the washout period $(n=2)$ or the EPSPs were not changed by VP $(n=1)$. None of these neurons showed a treatment-related change in RMP after peptide treatment (not shown). The mean $R_{(I N)}$ of these cells at $60 \mathrm{~min}(97.4 \pm 11.8 \%$ of controls $)$ differed little from that at baseline although the VP-induced increase in EPSPs in one neuron was associated with a $19 \%$ decrease in the $\mathrm{R}_{(\mathrm{IN})}$ but in another neuron with a $15 \%$ increase in the $R_{(I N)}$ (see Fig. 5).

In 8 cells, the effect of VP was studied in the presence of $50 \mu \mathrm{M}$ picrotoxin and $50 \mu \mathrm{M} \mathrm{D}$-APV in the medium. The antagonist-containing medium was superfused $30 \mathrm{~min}$ before VP and resulted in a $\sim 20 \%$ decrease in EPSPs. This decrease was compensated for (to original baseline level) by increasing the stimulus intensity. Fig. 6 summarizes the results obtained with these neurons and illustrates that a combined blockade of $\mathrm{GABA}_{\mathrm{A}}$ receptor-mediated inhibition and NMDA receptor-mediated excitation did not prevent the enhancing action of VP on EPSPs. Five of these neurons showed a long-lasting increase in the amplitude of EPSPs after VP administration. In 2 neurons we observed a temporary decrease in the EPSPs during $(n=1)$ or after $(n=1)$ the administration of VP. This decrease in EPSPs was associated with a slight decrease in $R_{(\mathrm{IN})}$. In one neuron EPSPs did not change. The mean $R_{(\mathrm{IN})}$ at 60 $\min (102.8 \pm 15.8 \%$ of the baseline) was little affected by VP.

\subsection{Effects of $V P(4-8)$}

The effect of VP(4-8) was studied in 13 neurons. In 3 neurons, EPSPs and $R_{(I N)}$ gradually and irreversibly de-
$\mathbf{A}$
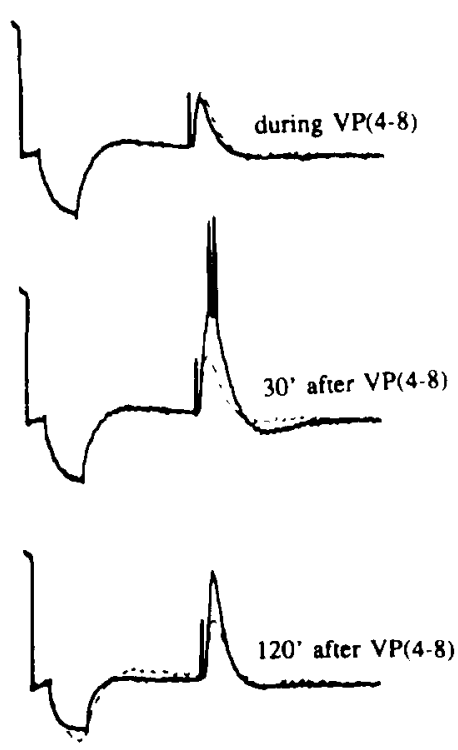

B

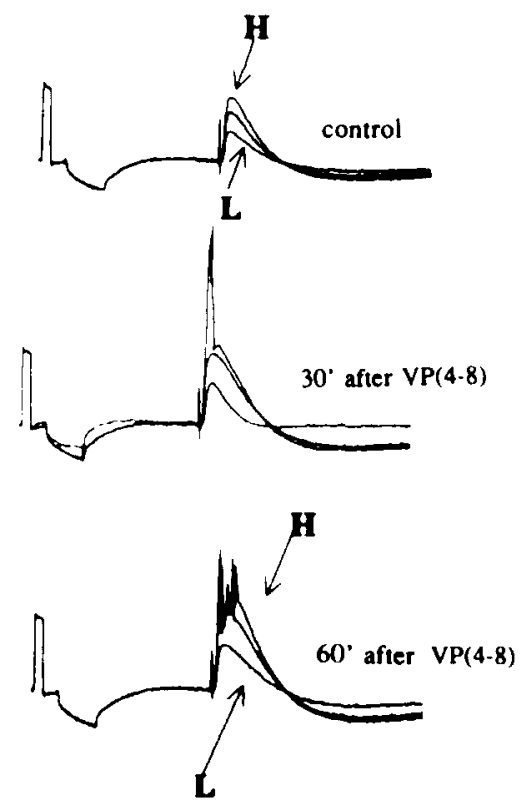

Fig. 8. A: Example of the effect of $0.1 \mathrm{nM} \mathrm{VP(4-8)}$ on average $(n=10)$ EPSPs in one neuron of the CAl/subiculum in the ventral hippocampus before (dotted line), during, 30 and 120 min the administration of peptide. Note the appearance of action potentials 30 min after the administration of VP(4-8). The response to hyperpolarizing current of $120 \mathrm{pA}$ in neuron A $120 \mathrm{~min}$ after the peptide administration decreased slightly. B: Example of the effects of $0.1 \mathrm{nM} \mathrm{VP}(4-8)$ on average EPSPs $(n=10)$ in another neuron, studied in the presence of $50 \mu \mathrm{M}$ picrotoxin and D-APV in the medium before, 30 and 60 min after the peptide treatment. Superimposed are responses to three different stimulus intensities: high (H), medium (middle sweep in the all panels), and low (L). At $60 \mathrm{~min}$, the medium stimulus intensity (the middle sweep in the lower panel) produced action potentials above the EPSPs while the EPSPs elicited by weak stimuli remained under the firing threshold of the neuron. The response to hyperpolarizing current injection temporarily decreased 30 min after peptide administration, indicating that $R_{(I N)}$ of the neuron decreased at this time, but it returned to the control level at 60 min (see lower panel). Calibration: $15 \mathrm{mV}$ and $5 \mathrm{~ms}(\mathrm{~A}) ; 10 \mathrm{mV}$ and $5 \mathrm{~ms}$ (B). 
clined during the washout period and data from these neurons were excluded from the final analysis. The results for the remaining 10 neurons are summarized in Fig. 7. The mean amplitude of the EPSPs at 60 min was significantly $(t=2.282 ; P<0.05)$ higher than the baseline level. The slope of the EPSPs also increased after peptide treatment, however, this increase was not seen in all the neurons in which the amplitude of EPSPs was potentiated by VP. The magnitude of the slope increase varied more than that of the EPSP amplitude. In 6 of these 10 neurons, EPSPs remained increased for the entire 60-120 min washout period (see example in Fig. 8A). In 3 neurons, the amplitude of the EPSPs initially increased but started to decline later during the washout, and 1 neuron showed no change in EPSPs after peptide administration. The mean $R_{(I N)}$ was little changed by VP(4-8) although temporary fluctuations in $R_{(I N)}$ were noticed in 3 of the neurons.

Three out of the 5 neurons that showed an increase in the EPSP amplitude also showed a steeper rising phase of the depolarization, a decreased threshold, and an increased number of action potentials in response to current injection (see example in Fig. 9A). The two remaining neurons showed no change in the threshold and the number of action potentials after VP administration.

The EPSP-enhancing effect of $\mathrm{VP}(4-8)$ was also seen in 4 out of 7 neurons in slices in which $\mathrm{GABA}_{\mathrm{A}}$ receptormediated inhibition was suppressed by $50 \mu \mathrm{M}$ picrotoxin in the medium. The EPSPs at $60 \mathrm{~min}$ after peptide application reached $129.1 \pm 11.9 \%$ of baseline, while the $R_{(I N)}$ was $94.3 \pm 7.3 \%$ of baseline. In 2 neurons the initial increase in EPSPs vanished during the washout period, and I neuron showed no change in EPSPs after VP(4-8) treatment.

Inclusion of $50 \mu \mathrm{M} \mathrm{D}$-APV in the picrotoxin-containing medium did not interfere with the facilitating effect of VP(4-8) on the amplitude of EPSPs. Fig. 10 summarizes the results for 9 neurons. The mean amplitude and slope of
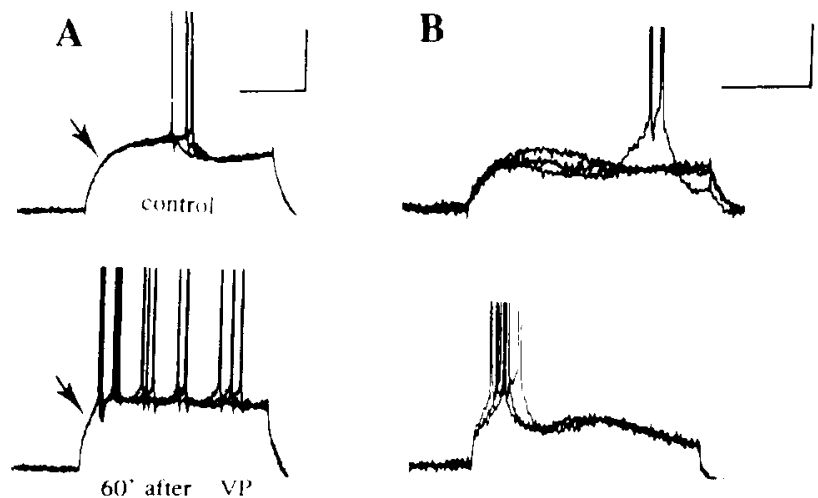

Fig. 9. Example of superimposed $(n=3)$ membrane responses to depolarizing current injection in two neurons of the $\mathrm{CA} 1$ /subiculum in the ventral hippocampus, studied in the control medium (A) or in a medium containing 50 $\mu \mathrm{M}$ picrotoxin and 50 $\mu \mathrm{M}$ D-APV (B). Note the steeper rising phase of the response and increased number of action potentials 60 min after VP(4-8) administration. Calibration: $10 \mathrm{mV}$ and $50 \mathrm{~ms}$
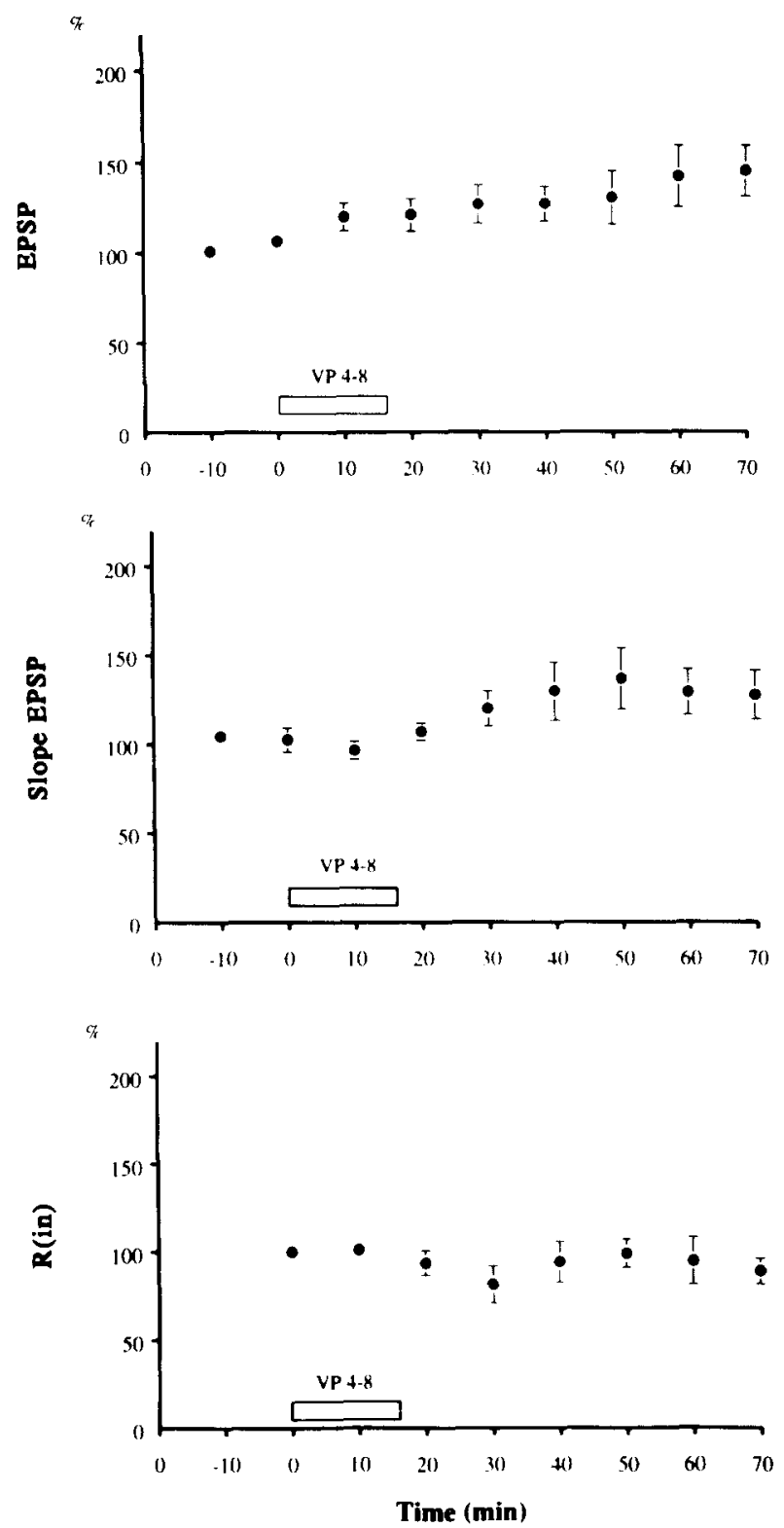

Fig. 10. Effect of $0.1 \mathrm{nM} V \mathrm{P}(4-8)$ on the amplitude (mean \pm SEM) and slope of the EPSPs (mean \pm SEM) and the input resistance $\left(R_{1 I N}\right)$ of nine neurons of the CAl/subiculum of the ventral hippocampus studied in a medium containing $50 \mu \mathrm{M}$ picrotoxin and $50 \mu \mathrm{M}$ D-APV. The values are expressed as percentages of the baseline values. Open har indicates the time of the 15-min administration of the peptide. The mean of the EPSPs at $60 \mathrm{~min}$ was significantly different from the controls $(t=2.572$; $P<0.05$ in two-tailed $t$-test for related measurements).

EPSPs at $60 \mathrm{~min}$ after peptide administration was significantly $(t=2.572 ; P<0.05)$ higher than the baseline value. However, the average amplitude increase in treated neurons was smaller than that in neurons exposed to the medium without antagonists, as 4 neurons showed a temporary decrease in the EPSP amplitude and $R_{(I N)}$ during or shortly after peptide administration, which partially reversed before the end of the $60 \mathrm{~min}$ washout period. The mean $\mathrm{R}_{(\mathrm{IN})}$ at $60 \mathrm{~min}$ was decreased by approximately $11 \%$ (not significant). VP(4-8) also increased the stimu- 
lus-response relationship in EPSPs when the antagonists were present in the medium (Fig. 8B). Two of 4 neurons tested showed an acceleration in the rising phase of the depolarization, a decrease in the latency, and an increase in the number of action potentials in response to current injection (see example in Fig. 9B).

\section{Discussion}

Our principal finding is that both VP and VP(4-8), in concentrations as low as $0.1 \mathrm{nM}$, facilitated excitatory transmission in a majority of the neurons studied in the CA1/subiculum of the ventral hippocampus. This facilitating action of the peptides often outlasted their administration by more than $60 \mathrm{~min}$, and it was frequently, though not always, accompanied by a long-lasting increase in the excitability of the postsynaptic membrane to depolarizing current injections. The blockage of $\mathrm{GABA}_{\mathrm{A}}$ receptormediated inhibition and NMDA receptor-mediated excitation did not prevent this effect of these peptides.

The increase in the amplitude and/or slope of the EPSPs, induced in the ventral hippocampus neurons by 0.1 nM VP or VP(4-8), was not associated with any consistent changes in the spontaneous activity, resting membrane potential, and input resistance of the neurons. Thus, the effect of the peptides on EPSPs was different from the reversible excitation observed by others in the hippocampus and in other brain neurons exposed to $10^{3}$ higher concentrations of VP and which is associated with membrane depolarization or an increase in firing rate or changes in input resistance $[10,38,43,47,50,51,70]$. Although antidromic stimulation was not used to identify the neurons tested, the average $R_{(I N)}$ and the appearance of after-hyperpolarization following an action potential in response to depolarizing current were similar to those observed in pyramidal neurons by others [7,37], suggesting that the majority of these neurons were the pyramidal neurons.

The notion that VP in very low concentrations potentiates the responses of brain neurons to excitatory, glutamatergic input came from earlier field potential [66] and microiontophoretic studies [29,67], and from recent intracellular experiments. Bath-applied 0.1-0.001 nM VP increased the amplitude of the EPSPs in lateral septum neurons, evoked by stimulation of the fimbria fibers, in nearly the same fashion as that described here. The EPSPS started to increase $10-20 \mathrm{~min}$ after the onset of VP application, reaching a maximum response at 30-45 min. In many lateral septum neurons, the EPSP increase remained for the entire $60-120 \mathrm{~min}$ washout period. The concentration of VP higher than $0.1 \mathrm{nM}$ increased only the duration of the peptide effect but not its magnitude [71]. Also in the ventral hippocampus, $0.1 \mathrm{nM}$ VP elicited a long-lasting increase in EPSP amplitude, and higher concentrations of the peptide increased the duration of the effect rather than its magnitude. This feature in the doseresponse relationship of $\mathrm{VP}$, in which the duration rather than the magnitude of the effect increases with increasing concentration of the peptide, has already been reported [45]. With 0.1 nM VP we could demonstrate the effect in a majority of the ventral hippocampus neurons impaled. This does not indicate $0.1 \mathrm{nM}$ concentration to be the lowest effective concentration of the peptide. A small increase in the field EPSPs in the CA1 and CA3 fields of the dorsal hippocampus was already elicited with $0.001 \mathrm{nM}$ VP [52], suggesting that a small population of the hippocampus neurons can be affected by this low peptide concentration. The threshold concentration of VP for potentiation of EPSPs in the ventral hippocampus can better be determined in a different kind of experiment.

Repeated VP administration failed to increase further the EPSP amplitude, suggesting that a saturation of this effect may occur after the first exposure to the peptide. This contrasts with the short-lasting excitation by VP which was seen after a repeated VP administration [45]. VP also potentiates the field EPSPs in the dentate gyrus [12]. However, 100-500 nM VP and low (1.5 mM) $\mathrm{Ca}^{2+}$ concentrations in the medium were needed to demonstrate this effect. Interestingly, in the presence of $2.5 \mathrm{mM} \mathrm{Ca}^{2+}$, the concentration used in the present study, VP decreased the field EPSPs in the dentate gyrus, suggesting that the mechanisms underlying the VP-induced potentiation EPSPs in the dentate gyrus might be different from th: underlying the facilitation of EPSPs in the CAl/subiculum of the ventral hippocampus. The short-lasting depression of the field potential in the CAl field of the hippocampus observed by Albeck et al. [2] after an intracerebroventricular injection of $500 \mathrm{ng} \mathrm{VP}$ could have been due to a short-lasting excitatory action of VP on inhibitory interneurons [46].

The observation that VP(4-8) facilitated EPSPs in the ventral hippocampus neurons in a similar manner as VP is new, demonstrating yet again that the biologically active metabolites of VP, such as VP(4-8) and VP(4-9), share some central effects with VP. Thus, centrally injected VP and $V P(4-8)$ and $V P(4-9)$ stimulate the maintenance of passive avoidance behavior $[9,19,21]$. Both VP and VP(49) facilitated the functional tolerance to ethanol $[60,61]$ and stimulated the release of acetylcholine from the hippocampus [40].

The receptor mediating these central effects of VP and VP metabolites, including the effect on EPSPs, has not yet been identified. It is possible that some of these central effects of VP might have been established after metabolism of VP into active metabolites, detected in the hippocampus [56]. Alternatively, they could be a result of an action of VP on binding sites specific for VP(4-8)/VP(4-9). Autoradiography with $\left[{ }^{3} \mathrm{H}\right]$ and/or $\left[{ }^{125} \mathrm{I}\right]$ ligands for the vascular $V_{1}$ type of $V P$ receptor and for oxytocin (OT) receptors revealed a distinct distribution of both $V_{1}$ and OT receptors in the hippocampus and in other brain areas. The dentate gyrus of the hippocampus contains predominantly high affinity $V_{1}$ type $V P$ receptors [34], while the 
subiculum / CAl field of the ventral hippocampus is rich in OT binding sites $[23,34]$ which have the same affinity for OT and VP [24,48]. Thus, OT receptors might be involved in the EPSP increase elicited by VP and VP(4-8). However, neither $\mathrm{VP}(4-8)$ nor $\mathrm{VP}(4-9)$, administered in a dose $10^{3}$ higher that the effective dose of OT, produces oxytocin-like effects on uterine muscle in vivo [14]. In addition, VP(4-9) fails to displace a $V_{1}$ receptor antagonist from its binding in the hippocampus [48]. The binding sites for $V P(4-9)$ in the brain, demonstrated with either $\left[{ }^{35}\right.$ S $]$ arginine ${ }^{8}$-VP $[5,15]$ or monoclonal anti-idiotypic antibodies [31], differ from those of VP/OT. These results and the recent finding of specific binding sites for $\mathrm{VP}(4-8)$ in synaptosomal membrane preparations from the anterior cortex [22] strongly suggest that many of the central effects of VP and its metabolites are mediated by specific receptor complex(es) distinct from the peripheral $V_{1}, V_{2}$ or OT receptors. The observation that many of the VP effects on the brain neurons are prevented by pretreatment of the neurons with $\mathrm{d}\left(\mathrm{CH}_{2}\right) 5-\mathrm{Ty}(\mathrm{Me})$-arginine ${ }^{8} \quad \mathrm{VP}$ $[38,45,47,67,70]$, shown to be a selective antagonist at the periheral $V_{1}$ pressor $V P$ receptor [36], might be misleading as this antagonist acts as a general neurodepressant agent [49]. Thus, further studies with various ligands for VP and for OT types of receptors might be a better approach for characterization of the receptors mediating the VP effect on EPSPs.

The mechanism involved in the VP and VP(4-8)-induced long-lasting enhancement of the EPSPs evoked in the $\mathrm{CA} /$ subiculum cells by stimulation of the stratum radiatum remains to be elucidated. The increase in the slope and the amplitude of these, presumably, glutamatemediated EPSPs [13] was not associated with a change in the RMP and/or $\mathrm{R}_{(\mathrm{IN})}$ of the neurons. A typical feature of the receptor-mediated long-term potentiation (LTP) of these EPSPs in the CAl of the hippocampus is that they depend on an influx of $\mathrm{Ca}^{2+}$ through the NMDA receptor-channel complex. The $\mathrm{Ca}^{2+}$ influx initiates the intracellular processes that lead to an increase in glutamate release, and enhances the sensitivity of postynaptic glutamate receptors (for review see [4]). VP and VP(4-8) still facilitated EPSPs in the presence of $\mathrm{GABA}_{\mathrm{A}}$ and NMDA receptor antagonists. $A$ decreased synaptic inhibition or increased $\mathrm{Ca}^{2+}$ influx through NMDA receptors is therefore unlikely to be the mechanism of the EPSP-potentiating action of the peptides. However, VP and VP(4-8) stimulate inositol phospholipid metabolism in neurons [44,54], mobilize $\mathrm{Ca}^{2+}$ from internal stores in cultured hippocampus neurons and in vascular smooth muscle cells $[6,72]$, and increase transmitter release [1]. Thus, VP and $V P(4-8)$ might have facilitated the EPSPs through a $\mathrm{Ca}^{2+}$-dependent mechanism, leading to an increase in glutamate release. However, a $\mathrm{Ca}^{2}$-induced increase in the sensitivity of postsynaptic receptors for glutamate, similar to that shown by LTP [4], accounts equally well for this effect of the peptides.
In most of the neurons studied, the peptide-induced increase in EPSPs was associated with a shortening of the rising phase of the voltage response to depolarizing pulses, and a decrease in the threshold and an increase in the number of action potentials elicited by sustained depolarization, suggesting that the conductances controlling the membrane response to a voltage step were affected by 0.1 nM VP peptides. The delay, threshold, and number of action potentials in hippocampal neurons in response to depolarizing current injection are predominantly determined by various components of the outward potassium current, such as the rapidly inactivating $\mathrm{I}_{\mathrm{A}}$, the rapidly activating and slowly inactivating $\mathrm{I}_{\mathrm{D}}$, and the $\mathrm{Ca}^{2+}$-dependent $I_{\text {AHP }}[3,26,37,39,53,58,59]$. A partial suppression of this current by VP or VP(4-8) would presumably decrease the delay and threshold and increase the number of action potentials during depolarization. Suppression of the outward potassium current might also be expected to decrease the threshold and increase the number of action potentials triggered by EPSPs, an effect seen in several of the neurons tested. Vasopressin closes ATP-sensitive $\mathrm{K}^{\text {' }}$ channels in cultured smooth muscle cells [74] and in insulin secreting cells [41]. This and other effects of VP on brain neurons, such as reversible depolarization, increase in input resistance and spontaneous activity, and activation of a voltage-dependent inward current $[38,43,47,51,75]$. could thus be a result of different intracellular effector pathways being activated by these peptides via the same or different membrane receptors. Activation of three different intracellular effector pathways by activation of the same $V P$ receptor has been demonstrated $[35,72]$. Two neurons showed a peptide-induced increase in EPSPs while the first action potential was delayed and the threshold increased. Thus, the peptide-induced increase in the rise time and decrease in the threshold of the action potential might have contributed to the increase in the slope and amplitude of EPSPs but it was not the sole cause of effect of the peptides on the EPSPs.

Finally, a drug that potentiated transmission through the hippocampus non-NMDA receptor type markedly improved performance in odor discrimination and water-maze tasks [57], suggesting that potentiation of transmission via these receptors may be important in the role played by the hippocampus in many forms of learning and memory [5.5]. The enhancing effect of peptides on non-NMDA glutamate receptor-mediated EPSPs suggests that VP and VP metabolites might have enhanced the memory function by this or a similar mechanism, namely by enhancing transmission though the non-NMDA type(s) of glutamate receptors. However, the block of the peptide effect with nonNMDA receptor antagonist needs to be demonstrated in order to support this notion. This, presumably, physiologically significant action of these peptides in the brain may be complementary to LTP, increasing transmission plasticity in those brain structures that are innervated by VP-releasing fibers. The facilitation by VP of I.TP expres- 
sion in the lateral septum [69] and the electron microscopic finding of vasopressin-containing synapses in the close vicinity of glutamate-containing terminals of the fimbria fibers on dendrites of the lateral septum neurons [27] support this notion.

\section{Acknowledgements}

The authors thank Dr. J.P.H. Burbach for his comments on the manuscript. A.N.Ch. and V.G.S were supported by grants from the International Science Foundation (MN 6000) and the Russian Foundation for Fundamental Science (94-04-11430).

\section{References}

[1] Abdul-Ghani, M., Meiri, H. and Rahaminoff, R., Vasopressin produces long-lasting increase in transmitter release, Brain Res., 515 (1990) 355-357.

[2] Albeck, D., Smock, T., McMechen, P., Purves, D. and Floyd, L., Peptidergic transmission in the brain. I. Vasopressin-like signal in the hippocampus, Brain Res., 511 (1990) 7-14.

[3] Alger, B.E., Characteristics of a slow hyperpolarizing synaptic potential in rat hippocampal pyramidal cells in vitro, J. Neurophysiol., 52 (1990) 892-910.

[4] Bliss, T.V.P. and Collingridge, G.L., A synaptic model of memory: long-term potentiation in the hippocampus, Nature, 361 (1993) $31-39$.

[5] Brinton, R.E., Gehlert, D.R., Wamsley, J.K., Wan, Y.P. and Yamamura, H.I., Vasopressin metabolite, AVP(4-9), binding sites in brain: distribution distinct from that of parent hormone, Life Sci., 38 (1985) 443-452.

[6] Brinton, R.D., Gonzales, T.M. and Cheung, W.S., Vasopressin-induced calcium signaling in cultured hippocampus neurons, Brain Res., 661 (1994) 274-282

[7] Brown, T.H., Fricke, R.A. and Perkel, D.H., Passive electrical properties in three classes of hippocampal neurons, J. Neurophysiol., 46 (1981) 812-827.

[8] Buijs, R.M., Intra- and extrahypothalamic vasopressin and oxytocin pathways in the rats, Cell Tissue Res., 192 (1978) 423-435.

[9] Burbach, J.P.H., Kovacs, G.L., De Wied, D., Van Nispen, J.W. and Greven, H.M., A major metabolite of arginine vasopressin in the brain is a higly potent neuropeptide, Science, 221 (1983) 1310-1312.

[10] Carpak, S., Dubois-Dauphin, M., Raggenbass, M. and Dreifuss, J.J., Vasopressin excites neurons located in the dorsal cochlear nucleus of the guinea-pig brainstem, Brain Res., 483 (1989) 164-169.

[11] Cherubini, E., Ben Ari, Y., Gho, M., Bidard, J.N. and Lazdunski, M., Long-term potentiation of synaptic transmission in the hippocampus induced by a bee venom peptide, Nature, 328 (1987) $70-73$.

[12] Chen, C., Diaz Brinton, R.D., Shors, T.J., and Thompson, R.F., Vasopressin induction of long-lasting potentiation of synaptic transmission in the dentate gyrus, Hippocampus, 3 (1993) 193-203.

[13] Collingridge, G.L., Herron, C.E. and Lester, R.A.J., Synaptic activation of N-Methyl-D-aspartate receptors in the Schaffer collateralcommissural pathway of the rat hippocampus, J. Physiol., 399 (1988) 283-300.

[14] De Jong, W., Gaffori, O., Van Ree, J.M. and De Wied, D.,
Differentiation of behavioral and peripheral actions of neuropeptides generated from vasopressin in the brain. In: R.W. Schrier (Ed.), Vasopressin, Raven Press, New York, 1985, pp. 189-194.

[15] De Kloet, E.R., Voorhuis, Th.A.M., Burbach, J.P.H. and De Wied, D., Autoradiographic localization of binding sites for the argininevasopressin (VP) metabolite VP(4-9), in rat brain, Neurosci. Lett. 56 (1985) 7-11.

[16] De Vries, G.J., Buijs, R.M., Van Leeuwen, F.W., Caffé, A.R. and Swaab, D., The vasopressinergic innervation of the brain in normal and castrated rats, J. Comp. Neurol., 233 (1985) 236-254.

[17] De Wied, D., Long term effect of vasopressin on the maintenance of a conditioned avoidance response in rats, Nature, 232 (1971) 58-60

[18] De Wied, D., The effects of neurohypophyseal hormones and related peptides on learning and memory processes. In: R.C.A. Frederickson, J.L. McGaugh and D.L. Felten (Eds.), Peripheral Signaling of the Brain, Hogrefe and Huber, Toronto, 1991, pp. 335-350.

[19] De Wied, D., Gaffori, O., Van Ree J.M. and De Jong W., Central target for the behavioral effects of vasopressin neuropeptides, $\mathrm{Na}$ ture, 308 (1984) $276-278$

[20] De Wied, D., Joëls, M. Burbach, J.P.H., De Jong, W., De Kloet, E.R., Gaffori, O.J.W., Urban, I.J.A., Van Ree, J.M., Van Wiemersma Greidanus, Tj. B., Veldhuis, D., Versteeg, D.H.G. and Wiegant, V., Vasopressin effects on the central nervous system. In: A. Negro-Vilar and P.M. Conn (Eds.), Peptide Hormones: Effects and Mechanisms of Action, CRC Press, Boca Raton, FL, 1989, pp. 97-140.

[21] De Wied, D., Elands, J. and Kovacs, G., Interactive effects of neurohypophyseal neuropeptides with receptor antagonists on passive avoidance behavior: mediation by a cerebral neurohypophyseal hormone receptor? Proc. Natl. Acad. Sci. USA, 88 (1991) 14671472.

[22] Du, J-C., Wu, J-H., Jiang, W-M. and Gu, Y-J., Characterization of binding sites of a memory-enhancing peptide AVP(4-8) in rat cortical synaptosomal membranes, Peptides, 15 (1994) 1273-1279.

[23] Elands, J., Beetsma, A., Barberis, C. and De Kloet, R., Topography of the oxytocin receptor system in rat brain: an autoradiographical study with a selective radioionidated oxytocin antagonist, $J$. Chem. Neuroanat., 1 (1988) 293-302.

[24] Freund-Mercier, M.J., Stoeckel M.E., Dietel, M.M., Palacios, J.M. and Richard, Ph., Quantitative autoradiographic mapping of neurohypophyseal hormone binding sites in the rat forebrain and pituitary gland. I. Characterization of different types of binding sites and their distribution in the Long-Evans strain, Neuroscience, 1 (1988) 261272.

[25] Gaffori, O.J.A. and De Wied, D., Time-related memory effects of vasopressin analogues in rats, Pharmacol. Biochem. Behat., 25 (1986) $1125-1132$

[26] Gustafsson, B. and Wigström, H., Evidence for two types of afterhyperpolarization in CA1 pyramidal cells in the hippocampus, Brain Res., 205 (1981) 462-468.

[27] Jakab, R.L.. Naftolin, F. and Leranth, C., Convergent vasopressinergic and hippocampal input onto somatospiny neurons of the rat lateral septal area, Neuroscience, 40 (1991) 413-421.

[28] Joëls, M. and Urban, I.J.A., The effect of microiontophoretically applied vasopressin and oxytocin on single neurons in the septum and dorsal hippocampus of the rat, Neurosci. Lett., 33 (1982) 79-84.

[29] Joëls, M. and Urban, I.J.A., Arginine-vasopressin enhances the responses of lateral septum neurons in the rat to excitatory amino acids and fimbria-fornix stimuli, Brain Res., 311 (1984) 201-209.

[30] Joëls, M. and Urban, I.J.A., Electrophysiological and pharmacological evidence in favor of amino acid neurotransmission in fimbriafornix fibers innervating the lateral septal complex of rats. Exp. Brain Res., 54 (1984) 455-642.

[31] Jurzak, M., Fahrenholz, F. and Gerstberger, R., Vasopressin anti-idiotypic staining in the rat brain: colocalization with 
$\left[{ }^{35} \mathrm{~S}\right]\left[\mathrm{pGlu}^{4}, \mathrm{Cyt}^{6}\right] \mathrm{AVP}_{(4-4)}$, binding sites, J. Neuroendocrinol, 5 (1993) $523-531$.

[32] Kovacs, G.L., Bohus, B., Versteeg, D.H.G., De Kloet, E.R. and De Wied, D.. Effect of oxytocin and vasopressin on memory consolodation: sites of action and catecholaminegic correlates after local microinjection into limbic-midbrain structures, Brain Res., 175 (1979) 303-314.

[33] Kovacs, G.. Veldhuis, H.D., Versteeg, D.H.G. and De Wied, D., Facilitation of avoidance behavior by vasopressin fragments microinjected into limbic-midbrain structures, Brain Res., 371 (1986) $17-24$.

[34] Kremarik, P., Freund Mercier, M.J. and Stoeckel, M.E., Histoautoradiographic detection of oxytocin- and vasopressin-binding sites in the telencephalon of the rat, J. Comp. Neurol., 333 (1993) 343-359.

[35] Kremer, S.G., Zeng, W., Sridhara, S. and Skorecki, K.L., Multiple signaling pathways for CL-dependent depolarization of mesengial cells: role of $\mathrm{Ca}^{2+}, \mathrm{PKC}$ and $\mathrm{G}$ proteins, Am. J. Physiol, 262 (1992) F $668-\mathrm{F} 678$.

[36] Kruszynski. M., Lammek, B., Manning, M., Seto, J., Halder, J. and Sawyer, W.H., [1-(beta-Mercapto-beta,beta-cyclopenta- methylenepropionic acid), 2-(O-methyl)-tyrosine] arginine-vasopressin and [1(beta-Mercapto-beta,beta-cyclopentamethelene-propionic acid)] arginine-vasopressin, two highly potent antagonist of the vasopressin response to arginine-vasopressin, J. Med. Chem., 23 (1980) 364-368.

[37] Lancaster, B. and Adams, P.R., Calcium-dependent current generating the afterhyperpolarization of hippocampal neurons, $J$. Neurophys., 55 (1986) 1268-1282.

[38] Ma. R.C and Dur, N.J., Vasopressin depolarizes lateral horn cells of the neonatal rat spinal cord in vitro, Brain Res., 348 (1985) 36-43.

[39] Madison, D.V. and Nicoll. R.A.. Control of repetitive discharge of rat pyramidal neurons in vitro, J. Physiol., 354 (1984) 319-331.

[40] Maegawa, H., Katsubc, N.. Okegawa, T., Aishita, H. and Kawasaki, A., Arginine-vasopressin fragment 4-9 stimulates the acetylcholine release in hippocampus of freely-moving rats, Life Sci., 51 (1992) $28.5-293$.

[41] Martin, S.C. Yule, D.I., Dunne. M.J., Gallacher, D.V. and Petersen, O.H. Visopressin directly closes ATP-sensitive potassium channels evoking membrane depolarization and an increase in the free intracellular $\mathrm{Ca}^{2}$ concentration in insulin-secreting cells, EMBO J.. \& (1989) $3595-3599$.

[42] Metzenger, D., Alescio Lautier, B., Bosler, O., Devigne, C., and Soumireu Mourat, B., Effect of changes in intrahippocampal vasopressin on memory retrieval and relearning, Behal: Neural Biol., 59 (1993) $29-48$.

[4.3] Mizuno, Y.. Oomura, Y. Hori, N. and Carpenter, D.O., Action of vasopressin on CAl pyramidal neurons in rats hippocampal slice. Brain R's., 309 (1984) 241-246.

[44] Moratallia, R., Vallejo, M. and Lightman, S.L., Vasopressin stimulates inositol phospholipid metabolism in rat medula oblongata. Brain Re's., 450 (1989) 398-402.

[45] Mühlenthaler, M., Dreifuss, J.J. and Gahwiller B.H., Vasopressin excites hippocampal neurons, Nature, 296 (1982) 749-751.

[46] Mühlenthaler, M., Charpak, S. and Dreifuss, J.J., Contrasting effects of neurohypophyseal peptides on pyramidal and non-pyramidal neurons in the rat hippocampus, Brain Res., 308 (1984) 97-107.

[47] Peters, S. and Kreulen. D.L., Vasopressin-mediated slow EPSPs in a mammalian sympathetic ganglion, Brain Res.. 339 (1985) 126-129.

[48] Phillips, P.A., Abrahams, J.M., Kelly, M., Paxinos, G., Grzonka, Z.. Mendelson. F.A.O. and Johnston, C.I., Localization of vasopressin binding sites in rat brain by in vitro autoradiography using a radioiodinated $V_{1}$ receptor antagonist. Neuroscience, 27 (1988) $749-761$

[49] Porter, J.P. and Brody M.J., A V1 vasopressin receptor antagonist has nonspecific neurodepressant actions in the spinal cord, Neuroendocrinology. 43 (1986) 75-78.

[50] Raggenbass. M.. Dubois-Dauphine, M., Tribollet, E. and Dreifuss.
J.J., Direct excitatory action of vasopressin in the lateral septum of the rat brain, Brain Res., 459 (1988) 60-69.

[51] Raggenbass, M.. Alberi, S. and Dreifuss, J.J., Effect of divalent cations on the current generated by vasopressin in facial motoneurons of the rat, Ann. NY Acad. Sci. 689 (1993) 567-569.

[52] Rong, X-W., Chen, X-F. and Du, Y-C.. Potentiation of synaptic transmission by neuropeptide AVP4-8 (ZNC(C)PR) in rat hippocampal slices, NeuroReport, 4 (1993) 1135-1138.

[53] Segal, M., Rogawski, J.M.A. and Barker, J.L.. A transient potassium conductance regulates the excitability of cultured hippocampal and spinal neurons, J. Neurosci., 4 (1984) 604-609.

[54] Shewey, L.M. and Dorsa, D.M., Vl-type vasopressin receptor in rat brain septum: binding characteristics and effect on inositol phospholipid metabolism, J. Neurosci, 8 (1988) 1671-1677.

[55] Squire, L.R., Memory and the hippocampus: A synthesis from findings with rat, monkeys and humans, Psychobiol. Rer.., 99 (1942) 195-231.

[56] Stark, H., Burbach, J.P.H., Van der Kleij, A.A.M. and De Wied, D., In vivo conversion of vasopressin after microinjection into limbic brain areas of rats, Peptides. 10 (1989) 717-720.

[57] Staubli, U., Rogers, G. and Lynch, G., Facilitation of glutamate receptors enhances memory, Proc. Natl. Acad. Sa. USA, 91 (1994) $777-781$.

[58] Storm, J.F., Temporal integration by slowly inactivating $\mathbf{K}^{*}$ current in hippocampal neurons, Nature', 336 (1988) 379-381.

[59] Storm, J.F.. An after-hyperpolarization of medium duration in rat hippocampal pyramidal cells, J. Physiol., 409 (1989) $171-190$.

[60] Szabó, G., Tabokoff, B. and Hoffman. P.I... Receptors with $V_{1}$ characteristics mediate the maintenance of ethanol tolerance by vasopressin, J. Pharmacol. Exp. Ther., 247 (1988) 536-541).

[61] Szabó, G., Tabakoff, B, and Hoffman, P.L., Comparative effects of arginine vasopressin $\left[\mathrm{pGlu}^{4}, \mathrm{Cyt} \mathrm{t}^{\dagger}\right.$ ]arginine vasopressin-(4-9) and nerve growth factor on maintenance of functional tolerance to ethanol in mice, Eur. J. Pharmacol. 199 (1991) 131-134.

[62] Tiberiis, B.E., McLennan, H. and Wilson, N., Neurohypophyseal peptides and the hippocampus, Neuropeptides, 4 (1983) 73-86.

[63] Tribollet, E.. Barberis, C., Jard, S.. Dubois-Dauphin, M. and Dreifuss, J.J., Localization and pharmacological characterization of high affinity binding sites for vasopressin and oxytoxin in the rat brain by light microscopic autoradiography, Brain Res., 442 (1988) 105-118.

[64] Urban, I.J.A., Brain vasopressin: from electrophysiological effects to neurophysiological function. In: E.R. de Kloet, V.M. Wiegant and D. De Wied (Eds.), Progress in Brain Research, Vol. 72, Elsevier. Amsterdam. 1987, pp. 163-172.

[65] Urban, I.J.A.. Rat lateral septum in slice preparation with viable transmission, Exp. Neurol., 95 (1987) 1-12.

[66] Urban, I.J.A. and De Wied, D.. Effect of vasopressin, oxytocin and peptides derived from these hormones on field potential induced in lateral septum of rats by stimulation of the fimbria fornix. No'uropeptides. 7 (1986) 41-49.

[67] Urban. I.J. and Killian, M.J.. Two actions of vasopressin on neurons in the rat ventral hippocampus: a microiontophoretic study. Ne'tropeptides, 16 (1990) 83-90. 1990.

[68] Urban. I.J.A. and French, P.J., Vasopressin elicits a lasting increase in excitatory postsynaptic potentials (EPSPs) in ventral hippocampus neurons. Annu. Mtg. Soc. Neurosci. 25-30) October 1992. 415.4.

[69] Van den Hooff. P., Urban, I.J.A. and De Wied. D., Vasopressin maintains long-term potentiation in rat lateral septum slice. Brain Res. 505 (1989) 181-186.

[70] Van den Hooff, P., Peppelenbosch. M. and Urban. I.J.A.. Vasopressin raises the excitability of dorso-lateral septum neurons in vitro. Neurosci. Res. Commun., 3 (1990) 17.3-180.

[71] Van den Hooff, P. and Urban, I.J.A.. Vasopressin facilitates excitatory transmission in slices of the rat dorso-lateral septum, Sinapse. 5 (1990) 201-206.

[72] Van Renterghem. C., Romey, (.. and Lazdunski. M.. Vasopressin 
modulates the spontaneous electrical activity in aortic cell (line A7r5) by acting on three different types of ionic channels, Proc Natl. Acad. Sci. USA, 85 (1988) 9365-9369.

[73] Walaas, I. and Fonnum, F., Biochemical evidence for glutamate as a transmitter in hippocampal efferents to the basal forebrain and hypothalamus in the rat brain, Neuroscience, 5 (1980) 1691-1698.
[74] Wakatsuki, T., Nakaya, Y. and Inoue, I., Vasopressin modulates $\mathrm{K}(+)$-channel activities of cultured smooth muscle cells from porcine coronary artery, Am. J. Physiol., 263 (1992) H491-H496.

[75] Widmer, H., Dreifuss, J.J. and Raggenbas, M., N-Methyl-D-aspartate and vasopressin activate distinct voltage-depepndent inward currents in facial motoneurons, Brain Res., 593 (1992) 215-220. 